\title{
Haiguse kujutamine luuletaja Ilmi Kolla kirjades ${ }^{1}$
}

\begin{abstract}
Eve Annuk
Teesid: Erakirjad on autobiograafiliste kirjutiste hulgas kõige vähem uuritud žanr. Sellele vaatamata võivad kirjad pakkuda rikkalikku uurimismaterjali selle kohta, kuidas haige inimene haigust kogeb ja kuidas ta seda oma kirjades kujutab. Artiklis käsitletakse haiguse kujutamist luuletaja Ilmi Kolla (19331954) kirjade põhjal, kasutades analüütilise vahendina (auto)patograafia mõistet. Keskendutakse küsimustele, kuidas haigust kirjades tekstualiseeritakse ja kuidas kirjažanr seda kujutamist vormib.
\end{abstract}

Märksõnad: haigusnarratiiv, kirjavahetused, Ilmi Kolla, patograafia, tuberkuloos

Haigus pole ainult meditsiiniline, vaid samavõrra kultuuriline nähtus. Haigust ja haige olemist tajutakse kultuuri ja keele kaudu: haigusi ümbritsetakse kultuuriliste tähendustega, mis on haigusest lahutamatud; haigusega seotud metafoorid määratlevad haigust ja haige olemist, meie kogemust haigusest. Sellele on viidanud ameerika kultuurikriitik Susan Sontag oma uurimuses Haigus kui metafoor, analüüsides erinevatele haigustele, nagu tuberkuloos ja vähk omistatud tähendusi. Ta leiab, et tuberkuloosi on sageli käsitletud kui hingehaigust, kui poeetide haigust, ja sellisena on tuberkuloos omandanud teatava romantilise oreooli, samas vähihaigust seostatakse märksa negatiivsemate tähendustega. Haigustele omistatud tähendused mõjutavad ka seda, kuidas haigusi kogetakse (Sontag 2002).

Kultuur määratleb, kellel ja kuidas on õigus haigusest rääkida, s.t paneb paika diskursiivsed võimusuhted, luues diskursiivse raamistiku. Lääne kultuuris domineerib haigusest rääkimise-kirjutamise puhul meditsiiniline diskursus: kõike haigusega seotut peetakse eelkõige meditsiini pärusmaale kuuluvaks, meditsiinilist vaatenurka haigustele peetakse kõige autoriteetsemaks, teaduslikult põhjendatuks.

Traditsioonilisemat vaatenurka haigustele ja haige olemisele esindab rahvameditsiin, mis peegeldab sajanditevanuseid traditsioone seoses haiguste ja 
nende raviga. Nüüdiskultuuris leidub haiguse kajastusi hulgaliselt ka kirjanduses ja kunstis, autobiograafilistes tekstides, filmides, meedias, internetis (nt blogid) jm. Need haiguse representatsioonid (haigusest rääkimise-kirjutamise viisid) toovad esile üksikindiviidi subjektiivse vaatenurga, mis vastandina meditsiinilisele diskursusele keskendub individuaalsele haiguskogemusele.

Haigus on ka väga eksistentsiaalne teema, seostudes olemuslike küsimuste, elu ja surmaga, mis muudabki haigused altiks mütologiseerumisele. Teisalt nähakse haigusi eelkõige negatiivsest vaatenurgast kui normaalse elu katkestust, mis piirab selle "normaalse elu" võimalusi ja sellele omistatavaid tähendusi.

Artiklis käsitlen haigust haige inimese vaatenurgast, kasutades allikmaterjalina tuberkuloosi surnud luuletaja Ilmi Kolla (1933-1954) kirjavahetusi, mis võimaldavad sissevaadet individuaalsesse haiguskogemusse 1950. aastate alguse stalinistlikus Eestis. Keskendun küsimustele, kuidas haigust kirjades tekstualiseeritakse ja kuidas kirjažanr seda kujutust vormib. Pööran tähelepanu ka sellele, kuidas suhestub konkreetne haiguse kujutamine ajastu sotsiokultuurilise kontekstiga.

\section{(Auto)patograafia mõistest}

Haigusest kirjutamine tähendab haiguse tekstualiseerimist, sellele tekstilise kuju andmist, olgu siis tegu pikema looga või haiguseteemalise luuletusega. Haiguskirjelduste kohta on kasutatud mõistet 'haigusnarratiivid', mis hõlmab nii inimese enda kirjapanekuid oma haigusest kui ka kellegi teise, tavaliselt lähedase inimese haigusest kirjutamist. Sellistena erinevad haigusnarratiivid meditsiinilisest haigusloost, mis on rangelt objektiveerivas vormis meditsiiniline ravidokument.

Haiguse tekstuaalset kujutust võib määratleda ka mõistega 'patograafia', mida kasutangi siinses artiklis analüütilise vahendina. Patograafia mõiste tähistab meditsiinilises diskursuses uurimust, mis käsitleb haiguse mõju inimese elule ja tegevusele. S. Freud kasutab sõna patograafia oma töös Leonardo da Vinci lapsepõlvemälestus, viitamaks biograafilisele uurimusele, "mis keskendub sellele, kuidas patoloogilised elemendid inimese elus valgustavad selle elu teisi tahke" (Hawkins 1999: 229). Eestiski on mõistet patograafia kasutatud kui inimese isiksuse hälvete ja nõrkuste kirjeldust, millele viitab ka Võõrsõnade leksikoni patograafia definitsioon (vt Vääri jt 2000).

Autobiograafiauuringute kontekstis on seda mõistet kasutatud haiguskujutuste tähistamiseks. Kirjandusuurija Anne Hunsaker Hawkins kasutab mõistet patograafia biograafiliste ja autobiograafiliste haiguskujutuste märgistamiseks, käsitledes seda autobiograafia alažanrina ning kaasates sinna alla nii 
päevikuid kui ka koostööna valminud teoseid, nagu ka biograafiaid - lähedase inimese surma kujutavaid narratiive, mis samas on ka autobiograafilised lood kirjutaja kui tunnistaja/pealtnägija kogemusest haigusega (Hawkins 1999: 3). Ta väidab, et patograafiad on inimlike dokumentidena olulised "mitte ainult sellepärast, et nad kujutavad traumaatilist kriisi, mis võib juhtuda igaühele meist, vaid ka sellepärast, et nad kujutavad nii oma kirjutuse kui ka selle sisu tõttu viise, kuidas neid kriise on võimalik ületada, üle elada ja mõista" (Hawkins 1999: xix). Patograafia võimaldab meile ettekujutust sellest, milline oleks meie olukord, kui meie igapäevaselt harjumuspärane korrastatud maailm äkki haiguse tõttu kokku kukuks. Meie argiilma näiv korrastatus ja koherentsus võib meile endilegi aeg-ajalt tunduda imena, kingitusena või juhusena, mis uueneb päev-päevalt, kuid enamik meist käitub nii, nagu oleks see ime endastmõistetav. Ja alles haigusega, mis lõhub igapäevase korrastatuse, saabub ka arusaam sellise korrastatud maailma haprusest. Patograafiad toovadki esile selle võimaluse: elu mõtte ja eesmärgi drastilise katkestamise haiguse poolt, mis "näib sageli meelevaldse, julma ja mõttetuna; nagu ka raviprotseduurid, mis samuti võivad sageli tunduda sama meelevaldsed, julmad ja mõttetud - eriti indiviidile, kes peab neid taluma" (Hawkins 1999: 2). Patograafiad on seotud indiviidi vajadusega orienteeruda haiguste maailmas,"et saavutada uut tasakaalu enese ja reaalsuse vahel, et jõuda objektiivse suhtumiseni nii kogemusse kui kogevasse minasse" (samas). Patograafia autori eesmärk "ei ole ainult korrastatust lõhkuva protsessi kujutamine, vaid ka reaalsusele selle kaotatud koherentsuse tagasiandmine ning selle tähenduse, mis võiks maailma jälle kokku siduda, leidmine või taasloomine" (Hawkins 1999: 3).

Anne Hunsaker Hawkins on viidanud patograafiatele kui haigust tänapäeval ümbritsevate müütide rikkalikule reservuaarile, sest need tekstid on isikliku kogemuse interpretatsioonid, mida saab analüüsida kui konstruktsioone või mõnikord ka kui loovaid moonutusi, mis toovad esile erinevaid ideoloogilisi ja müütilisi hoiakuid, mis haigust tänapäeval ümbritsevad (Hawkins 1999: 25).

Kirjandusuurija Thomas Couser on kasutanud "autopatograafia" (auto 'ise' + pathos 'kannatamine, haigus' + grapho 'kirjutama') mõistet, viitamaks "autobiograafilisele narratiivile haigusest või puudest" (Couser 1999: 164) ehk siis inimese enda jutustusele oma haigusest. Sellised tekstid ulatuvad päevikuvormis lugudest esseede ja kogu elu katvate autobiograafiliste narratiivideni. Haigus võib neis lugudes olla tagaplaanil, kuid tavaliselt on see esiplaanil, olles narratiivist lahutamatu. T. Couseri sõnul on autopatograafia areng "kultuurilise tervise" märgiks: see tähendab "meie olukorra kui kehastunud minade tunnistamist ja uurimist" (an acknowledgement and an exploration of our condition as embodied selves) (Couser 1999: 164). Autopatograafia on õitsele löönud Teise maailmasõja järel, eriti aga viimastel aastakümnetel (Couser 1997: 
5, 7). Ameerikas on selle žanri õitseng langenud kokku puuetega inimeste õiguste eest võitlemise liikumisega ja puuetega inimeste seaduse vastuvõtmisega 1990. aastal (Haugen 2006: 8).

Autopatograafia on seega haige inimese lugu, autobiograafiline kirjutis haigusest või invaliidsusest. Ent Thomas Couseri arvates on autopatograafial ka teine tasand, sest autopatograafiat võib mõista ka vastupanuna. Autopatograafia on vastudiskursuse vorm, s.t selline haiguse kujutamine vastustab kultuurilisi diskursusi, mis stigmatiseerivad haiget inimest kui patoloogilist. T. Couser leiab selliste tekstide kultuurilisi tähendusi analüüsides, et neil on hegemooniat vastustav potentsiaal, mis tähendab, et neil haiguse narratiividel on potentsiaali toimida kultuurilise vastudiskursusena domineerivate meditsiiniliste haiguse representatsioonide suhtes. Nende haiguse narratiivide funktsioon on destigmatiseerida haigust ja invaliidsust (Couser 1997: 8), kuna biomeditsiiniline paradigma võõrandab meid meie kehadest (Couser 1997: 10). Ta rõhutab samuti, et haigusnarratiivid valgustavad keha, mõistuse ja hinge vahelisi suhteid (Couser 1997: 12). Autopatograafiad kui haiguskujutused on uudne elulugude kategooria, sest neis käsitletakse somaatilist kogemust uuel moel: keha mõistetakse kui identiteedi fundamentaalset osa (Couser 1997: 12). Küsides, millal muutub haigusnarratiiv üldisemaks autobiograafiliseks kirjutiseks ehk millal hakkab haiguskujutus esindama elu tervikuna, leiab T. Couser, et somaatiliste düsfunktsionaalsuste narratiividel "on kalduvus muutuda elust kirjutamiseks (life writing) sel määral, kuivõrd kirjutaja identifitseerib ennast kehaga" (Couser 1997: 14).

Eestis on patograafia suhteliselt uus žanr, raamatumahus patograafiaid on meil avaldatud veel üsna vähe. Võib oletada, et oma haigusest avameelselt kirjutamine ei ole varem kuulunud avalikku diskursusesse. Haiguskogemust on peetud privaatseks ja küllap on taustana mõju avaldanud ka nõukogudeaegsed arusaamad, mille järgi haigusest kirjutamine oli eelkõige meditsiini pärusmaa, sest arstiteadust peeti kõige autoriteetsemaks haiguste käsitlejaks.

Siiski on viimasel ajal hakanud ilmuma ka sedalaadi tekste. Avaldatud patograafia heaks näiteks on Aive Raudkivi 2003. aastal ilmunud raamat Pilvedesse poodud lind, mis sai autori sõnul alguse haiglasoleku jooksul kodustele saadetud kirjadest (Raudkivi 2003). Irja Kassi 2008. aastal ilmunud raamat Kuidas ma lähen on vähihaige naise Taimaa reisi lugu, mis autori sõnul sai samuti alguse kirjadest lähedastele (Kass 2008). Mõlemad tekstid kujutavad rasket, parandamatut haigust, mille kujutamisviisi iseloomustab kirjutaja püüd olla haigusest üle, vaadata sellele ka läbi huumoriprisma. Haigusega hakkamasaamine, sellele tähenduse otsimine, mis aitaks toime tulla ebaõiglasena tunduva saatusega, on nende tekstide keskseid motiive. Need haiguskujutused võimaldavad sissevaadet haige inimese individuaalsesse haiguse kogemusse. 


\section{Haiguse kajastumine Ilmi Kolla kirjades}

Ajalooliselt on haiguskujutused keskendunud teatud haigustele, näiteks tuberkuloosinarratiivid olid väga levinud 19. sajandil (Couser 1997: 8). Tuntud on ka 19. sajandi kuulsate kirjanike haiguskujutused, näiteks Charles Darwini autobiograafia, kus ta käsitleb oma vaimuhaigust, või Dorothy Wordsworthi päevikud (Jolly 2001: I, 457).

Haigusest kirjutamine ei piirdu ainult raamatumahus narratiividega, vaid see on alati eksisteerinud ka sellistes vormides, mis ei ole olnud mõeldud laiemale lugejaskonnale, nagu kirjad või päevikud. Sellistes vormides lood haigustest on enamasti algselt mõeldud iseendale või kirjapartnerile (nagu kirjavahetuse puhul), aga hiljem on neid mõnikord ka avaldatud.

Päevikuvormis haiguskujutusi on siiski vähesel määral uuritud, ent haiguse kujutamisele kirjades on pööratud väga vähe tähelepanu. Ometi on kirjad kui autobiograafilised tekstid sellest aspektist rikkalikuks allikmaterjaliks, eriti Eesti kontekstis, kus raamatuna avaldatud patograafiad on senini veel suhteliselt vähe.

Kuivõrd saab kirjades avalduvat haiguskujutust üldse käsitleda haigusnarratiivina, (auto)patograafiana? Kuigi Anne Hunsaker Hawkins peab patograafia all silmas eelkõige raamatumahus haiguskujutusi, leiab ta, et ka päevikutes või kirjades leiduvad haiguseteemalised sissekanded, kui need on piisavalt pikad ja detailsed, võivad kvalifitseeruda patograafilise kirjutusena (Hawkins 1999: xv).

Kirjade puhul tuleb pöörata tähelepanu sellele, kuidas haiguskogemust tekstualiseeritakse ja kuivõrd kirjavormi eripära seda kujundab. Kirjad eristuvad autobiograafiliste kirjutiste kontekstis selles mõttes, et nad ei esita lineaarset narratiivi (näiteks võrreldes traditsioonilise autobiograafiaga), vaid nad moodustavad pigem ruumilise kommunikatsioonivõrgustiku, sest kirjad kui saatja ja adressaadi vahelised sõnumid on ajas ja ruumis laiali paisatud. Erinevalt suurest osast autobiograafiatest ei ole isiklikud kirjad enamasti mõeldud avaldamiseks, välja arvatud juhtumid, kui nende autor, näiteks tuntud isik, kirjutab teadlikult silmas pidades laiemat auditooriumi kui ainult adressaat. Adressaadi erinevus isiklike kirjade ja (avaldamiseks mõeldud) autobiograafiate puhul määratleb osaliselt ka nende tekstide sisulisi ja vormilisi jooni.

Et kirjad ei moodusta traditsioonilist lineaarset ja koherentset narratiivi, erineb kirjade haiguskujutus traditsioonilisest haigusnarratiivist mitmes aspektis. Kirjades võib haiguse kujutamine olla mitmekihilisem, kuna autor võib kirjutada oma haigusest samaaegselt mitmele erinevale adressaadile, kohandades haiguse kujutamist vastavalt adressaadi eripärale. Haiguse kujutamist kirjades iseloomustavad katkestused: erinevatel ajaperioodidel kirja pandud 
haiguskujutused on eraldatud ajaliste ja ruumiliste intervallidega erinevate kirjade vahel. Haiguse kajastumine võib kirjades olla ka kronoloogiline, sest kronoloogiliselt dateeritud kirjad loovad järk-järgult narratiivi vastavalt haiguse arenemisele ja selle sümptomite avaldumisele ning vastavalt sellele, kuidas autor seda tajub. Haiguse kujutamine kirjades on ka kontekstualiseeritud, s.t seotud sotsiokultuurilise kontekstiga ja erinevaid haigusi ümbritsevate kultuuriliste müütidega.

Tuberkuloosi surnud luuletaja Ilmi Kolla (1933-1954) kirjad on heaks näiteks haiguse kujutamisest kirjades, sest ta kirjutas oma kirjades haigusest suhteliselt palju elu lõpuaastatel 1953-1954, mil kopsuhaigus oli süvenenud ja ta veetis pikki perioode sanatooriumis ja haiglas. Ilmi Kolla kajastab haigust sellisena, nagu ta seda reaalselt koges, s.t küllaltki realistlikult või isegi naturalistlikus võtmes. Luuletaja toob oma kirjades esile haiguse iseloomulikke detaile ning kajastab oma haiguskogemust ja sanatooriumielu küllaltki põhjalikult.

Haiguskogemus kajastub ka Ilmi Kolla loomingus, ent teistsugusel kujul. Susan Sontagi järgi (1978) mõjutavad kultuurilised tähendused, mida haigustega seostatakse, neid viise, kuidas haigusi mõistetakse ja kogetakse. Haigusena on tuberkuloosi romantiseeritud, seda on peetud luuletajate haiguseks. Haiguse tegelik kogemus on olnud varjatud selle romantilise kultuurimüüdi taha. Ilmi Kolla luule võimendab romantilist tuberkuloosimüüti, ta luuletuste romantiline kujundistu romantiseerib ja mütologiseerib haigust. Seevastu ta kirjad pakuvad usaldusväärsemat ettekujutust haige olemise kogemusest.

Tuberkuloos avastati Ilmi Kollal 15-aastaselt, 1948. aastal. Haiguse algjärgus, kui luuletaja tervis oli veel suhteliselt hea, kirjutas ta haigusest oma kirjades suhteliselt vähe. Alates 1953. aastast pühendas ta sellele kirjades rohkem ruumi. Ka haiguse kujutamise tonaalsus muutus koos haiguse arenguga, sest tuberkuloosiga kaasnenud mitmesugused kehalised sümptomid, nagu köha või kaalulangus, panid Ilmi Kollat muretsema oma tervise pärast.

Kõige detailsemalt kujutas Ilmi Kolla oma haigust kirjades emale, ent ka sõbratarile Lehti Metsaaltile ja luuletaja Debora Vaarandile saadetud kirjades kirjutas ta sellest. Emale kirjutas Ilmi Kolla optimistlikumas toonis, püüdes varjata oma tervise tegelikku seisundit, et ema mitte muretsema panna. Isegi oma viimases, saatmata kirjas, mis on kirjutatud 12 päeva enne surma haiglas, püüdis ta säilitada positiivset hoiakut. Seevastu Debora Vaarandile saadetud kirjades kirjutas ta haigusest märksa pessimistlikumas toonis, pihtides avameelselt ka oma hirmu suremise ees:

Tere seltsimees Vaarandi! Teie kirja sain kätte alles hiljuti. Seisis mitmel pool, ja nüüd jälle polnud mul jõudu vastata. Olen väga ebameeldivas kohas ja veel ebameeldivamas olukorras: Tallinna Tub. Dispanseri Stat- 
sionaaris voodis ja lõpmatult voodis. Seekord mind toodi, omal jalal ei tulnud enam. Kõigile siin on omane optimism, mul ka, kuid ometi teised kõik käivad üleval, jalutavad aias, müravad, kuna mina ei jõua tõusta. Paha on see, sm Vaarandi. Olen ise lõpmatult sü̈di, kuid kes märkab seda õigel ajal. Ja nü̈̈d ma mõtlen sellest, millest varem ei mõelnud: surra ei taha veel. Andestage. (I. Kolla D. Vaarandile 2. juuli 1954. EKLA, reg. 11/1993.)

Kirjades kirjutab Ilmi Kolla oma tervisest, haiguse sümptomitest ja ka ravist, mida ta sai. Kirjas Debora Vaarandile tunnistab ta, et haigus katkestas ta õpingud keskkoolis ning isegi balletitunnid (I. Kolla D. Vaarandile 29.-30. sept. 1952. EKLA f 220, m 1:6). Seda, et haigus lõi segi ta edasiõppimisplaanid, on ta kajastanud isegi oma luules. 1948. aastal on ta kirjutanud pealkirjata luuletuse, kus ta protesteerib selle vastu, et teda ei lubatud haiguse pärast edasi õppida, võttes sel moel temalt tulevikuväljavaated.

Haiguse varasemas staadiumis olid Ilmi Kolla jaoks rahutuks tegevad sümptomid väsimus ja kaalulangus: ta oli sunnitud kirjades kodustele tunnistama, et tema tervisega on midagi korrast ära. Samal ajal püüdis ta kirjades sõbratarile veenda teda (ja võibolla selle kaudu ka iseennast), et ta ei ole enam haige ega kavatse sanatooriumi minna:

Tead, nü̈̈ on selge, et tulen Tallinnasse tagasi. Tööle vast mitte, kuid muidu ikka jäädavalt. Haige ma enam pole, tahaks jälle elu ja inimesi. (I. Kolla L. Metsaaltile 6. sept. 1952. EKLA f 220, m 1:4.)

Kirjad toovad esile ka Ilmi Kolla hoiaku haiguse ravimise suhtes. Tõenäoliselt ei olnud Ilmi Kolla hea patsient: ta ei käinud paar aastat üldse arsti juures ega saanud seetõttu ka õigeaegselt ravi. Huvi oma tervise vastu hakkas ta tundma siis, kui ei saanud enam ignoreerida haiguse sümptomeid. Samuti on tekitanud temas kahtlust haiguse tõsiduse suhtes arst, kes rääkis temaga liiga lahkelt: "Ise mõtlen, et ei tea kas olen väga haige, et minuga nii õrnalt ja ettevaatlikult räägitakse" (I. Kolla kodustele 4. dets. 1953. EKLA, f 220, m 1:1).

1954. aasta juulist algas Ilmi Kolla viimane pikem haiglaperiood (mis kestis surmani 1954. aasta detsembris) Tallinnas Kivimäe tuberkuloosihaiglas, kus tal seisis ees raske operatsioon. Seetõttu on ta kirjutanud põhjalikult ka operatsioonist - torakoplastikast - ja selle võimalikest tagajärgedest, võimalusest invaliidistuda. Torakoplastika tähendas ribide täielikku või osalist eemaldamist ühelt rindkere poolelt eesmärgiga suruda haigestunud kops kokku. Operatsiooni poolt- ja vastuargumentide kaalumine on Ilmi Kolla jaoks olnud raske ja ta on sellest kirjutanud nii emale kui luuletaja Debora Vaarandile, kes tundis huvi ta käekäigu vastu. Operatsioonist kirjutamine toob esile kehalisuse temaatika: noore kena naisena oli Ilmi Kolla mures selle pärast, et ta 
võib kaotada oma kehalise veetluse ja muutuda invaliidiks. Sellest kirjutas ta 1954. aasta augustis Debora Vaarandile, tunnistades ausa otsekohesusega, et tal ei ole kelleltki nõu küsida ja et ta peab selle raske otsuse ise langetama:

Komisjon otsustas teha mulle ribilõikus. Vast kuu aega tuleb siin veel niisamuti oodata, siis lähengi lauale. Kardan küll päris tõsiselt. Võibolla operatsiooni ennast ei kardagi nii, kui just seda, millisena tunnen end pärast. [---] Olukord on üsna raske, võibolla ei ela ma kuigi kaua, kui jätaksin niisamuti ja ei laseks opereerida. Aga kui anda ribid, poole aasta pärast teisel poolel ka - mis jääb minust järele siis! (I. Kolla D. Vaarandile 14. aug. 1954. EKLA, f 220, m 1:6.)

Naiselikkuse kaotamisega seotud hirmud ongi luuletaja jätkuvateks kaaslasteks ta elu viimasel poolaastal, sest operatsioon võeti ette alles 1954. aasta detsembris, mil arstid pidasid ta tervist selleks piisavalt tugevaks.

Haiguse kehalised kujutised Ilmi Kolla kirjades toovad esile ka soolisi tähendusi, sest kirjades kujutatav keha on naise õrn ja haavatav keha, vastukaaluks stalinismiaja avalikus diskursuses (nt meedias) domineerivale atleetlikule, jõulisele ja tervele naisekehale. Haigus - tuberkuloos - on see, mis võtab kehalise jõu, muudab haige inimese enesetunnet ning piirab kehalisi tegevusi ja kehalist võimekust, pannes mõtlema ka eksistentsiaalsetele küsimustele.

Teisalt peidavad kirjad ka kehalisuse soolisi külgi, sest mõned aspektid on kehakujutusest välja jäetud. Catherine Kohler Riessman ongi väitnud, et ajalooline kontekst kujundab teemasid (nagu näiteks seksuaalsus), mida saab lisada haigusnarratiivi (Riessman 2002: 26). Seda tõdemust saab laiendada ka kirjades loodud haiguskujutusele. Kuigi erakirjad on privaatsed tekstid, võivad nad kajastada ajastu avalikke diskursusi või olla ajastust teisiti mõjutatud, näiteks selle mõttes, et tabuteemad kirjades ei kajastu. Ilmi Kolla kirjad ei paljasta naisekeha toimimise eripäraseid aspekte või - mis on tema arvukaid meessuhteid arvestades olulisemgi - võimalikke probleeme kontratseptsiooniga. Viimane võis olla probleemiks stalinistlikus ühiskonnas, kus abort oli keelatud (see legaliseeriti alles pärast Stalini surma 1955. aastal) ning kontratseptsioon suhteliselt kättesaamatu.

Ilmi Kolla kirjades kujutatakse ka sanatooriumites veedetud pikki perioode. Kirjeldatakse sanatooriumite sotsiaalset elu ja eripärast subkultuuri, mis hõlmas nii mees- ja naispatsientide vahelisi (flirtimis)suhteid kui ka nõukogude sanatooriumielu eriomaseid jooni, nagu näiteks seinalehtede tegemine, näidendite lavastamine jm isetegevus, mida patsiendid sanatooriumis harrastasid. Ametisse oli võetud isegi spetsiaalne kultuuritöötaja, kes pidi hoolitsema isetegevuse ja meelelahutuse eest. 
Ent sanatooriumielul oli ka tumedam poolus, mis kujundas sealset õhustikku, kuna paljud ravil olnud patsiendid surid tuberkuloosi. Seetõttu leidub ka Ilmi Kolla kirjades jõulisi tuberkuloosi surevate patsientide kirjeldusi:

Eile oli ärev öö - üks oli suremas. See oli üks mees, kellele on pandud hõbedast kunstlik kõri. Tal juhtus midagi, öösel tehti kähku operatsioon. Öö läbi õed ja arstid jooksid. Aga läks korda, jäi elama.

Kuid üks noor tüdruk suri. Toodi siia sisse, kops ainult löga. Eile lahati surnukuuris. Ei saanud talle enam mingit operatsiooni teha, toideti pärasoole kaudu, ainult lamas. Polnud absoluutselt lootust. Õhtuti oli siis ärev ja veidi jube. (I. Kolla kodustele 21. aug. 1954. EKLA, f 220, m 1:1.)

Kuigi tuberkuloosi suremine oli sanatooriumis tavaline, püüdis Ilmi Kolla oma kirjades emale näidata seda ka optimistlikumas tonaalsuses:

Siin on inimesed väga elurõõmsad, on kirjutamata seaduseks mitte rääkida haigusest. Voodis lamajaid pole ainsatki. Ometi on 1/3 nendest, kellega eelmisel korral koos olin, nüüd juba surnud. On kaks võimalustsaada täielikult terveks või surra. Võib ju vireleda aastaid, kuid tulemus on sama. Üle kolme-nelja aasta haigeid vaevalt leidub. (I. Kolla kodustele, d-ta kiri. EKLA, f 220, m 1:1.)

Siiski võib surma-temaatika kajastuses näha ka hirmu ja ebakindlust, mida Ilmi Kolla püüdis oma vanemate eest varjata, kuna ta ei tahtnud neid enda pärast muretsema panna, sest ka Ilmi Kolla isa oli samal ajal väga haige. Luuletaja vajas tegelikult ise moraalset tuge raske otsuse ees, kas anda nõusolek operatsiooniks või mitte.

Sotsiaalajaloolane Sheila Rothman on väitnud, et kaaspatsientide haiguse kulust kirjutamine tähendab teatavas mõttes silmitsi seismist kas omaenda paranemise või surmaga, sest teiste haigete haigussümptomite arengu kaudu on võimalik ette näha ka omaenda saatust (Rothman 1995: 234). Selles kontekstis võib väita, et Ilmi Kolla haigus, sellega seotud lootused ja hirmud peegelduvad ka selles, kuidas ta kirjeldas kaaspatsientide haiguskogemust.

Haigus muutub Ilmi Kolla kirjades nähtavamaks järk-järgult kooskõlas selle arenguga. Kirjade põhjal võib järeldada, et ta suhtumine oma haigusesse sarnaneb krooniliste haigete suhtumisega, mis sõltub terviseseisundist ja haigussümptomite olemasolust või ajutisest puudumisest, sest kroonilistel haigustel on kalduvus võnkuda ägenemis- ja vaibumisperioodide vahel (Kleinman 1988: 7).

Tekstuaalsete haiguskujutuste kõrval sisaldavad Ilmi Kolla kirjad ka visuaalseid elemente, nagu joonistusi, mis on käsitsi kirjutatud kirjadele üldi- 


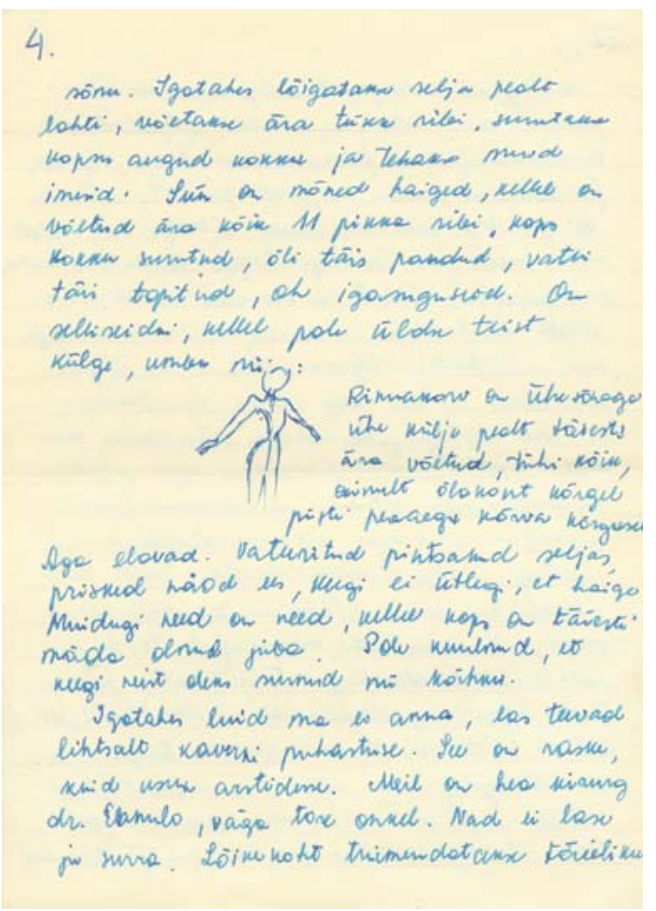

Ilmi Kolla kiri kodustele 02. aug. 1954.

(EKLA, f 220, $m$ 1:1.)

selt iseloomulik. Ühes oma kirjas on Ilmi Kolla kujutanud operatsioonijärgset deformeeritud keha, mille ühel poolel puuduvad ribid. See ilmekas joonis viitab ees ootavale operatsioonile - torakoplastikale. Haige keha visuaalne kujutis joonistusena lisab tuberkuloosile oma tähendusvarjundi, murendades romantilist käsitlust sellest haigusest ning tuues esile selle invaliidistava ja eluohtliku olemuse.

Haiguse kujutamine Ilmi Kolla kirjades moodustab kontrasti haigusega seotud avalike diskursustega (nt meedia) sõjajärgses stalinistlikus Eestis, kus püüti pigem esitada ilustatud pilti meditsiini olukorrast ja erinevate haiguste ravivõimalustest Nõukogude Liidus. Seetõttu võib ka väita, et Ilmi Kolla kirjades avalduv haiguskujutus vastustab ajastu domineerivaid diskursusi ja kirjade kaudu kujunevat haiguse lugu võib käsitleda autopatograafiana Thomas Couseri määratluses.

Sõjajärgsete aastate nõukogude avalikus diskursuses ei kajastatud eriti haiguse ja puuetega seonduvat, sest haiguste kujutamine ei sobinud kokku ideoloogilise püüdega kujutada nõukogude elu õnnelikuna. Puuetega inimesed olid nähtamatud nii sõna otseses mõttes (näiteks olid puuetega lapsed suletud spetsiaalsetesse institutsioonidesse) kui ka meedia tasandil. Meedias domineeriv visuaalne imago tõi esile terve, tugeva ja atleetliku mehe- või naisekeha, sellise, nagu on kujutatud Vera Muhhina skulptuuril “Tööline ja kolhoositar" (mis loodi 1937. aastal Pariisi maailmanäituse jaoks). Diskursiivsel tasandil mõisteti haigust ja kehalisi puudeid millegi negatiivse või isegi dekadentlikuna, mida on võimalik ületada tänu nõukogude meditsiini saavutustele. Ametlik propaganda püüdis näidata nõukogude meditsiini ja selle saavutusi eesrindlikuna, luues optimistliku diskursuse erinevate haiguste suurepärasest ravimisest Nõukogude Liidus. See kajastus ka statistikas, mis näitas tegelikkust ilustatuna ega olnud seetõttu alati usaldusväärne. 
Terve keha ja füüsilise tervise ametlik kultus ning nõukogude meditsiini saavutuste ülistamine ei jätnud eriti võimalusi inimeste endi haiguskogemuse väljendamiseks. Sellises ideoloogilises kontekstis ei olekski olnud võimalik avaldada haigusnarratiive või kirjeldada avalikus sfääris patsiendi kogemusi oma haigusest, sest see oleks läinud vastuollu stalinistlike ideoloogiliste ettekirjutustega õnnelikest nõukogude inimestest ja õnnelikust elust nõukogudemaal. Ideoloogilised ettekirjutused puudutasid ka ilukirjandust, mis pidi samuti kujutama elu positiivses võtmes. Seetõttu peeti isegi neid Ilmi Kolla luuletusi, mille teemaks oli nukrus elu kaduvuse üle, dekadentlikeks ja neid ei olnud võimalik avaldada luuletaja eluajal. Ka Ilmi Kolla sanatooriumikogemusi peeti dekadentlikeks ja väikekodanlikeks, nagu kirjutas talle luuletaja Debora Vaarandi vastuseks Ilmi Kolla sanatooriumielu kujutavatele kirjadele (D. Vaarandi I. Kollale 25.05. 1954. EKLA, f 220, m 4:14). Ainsaks haiguskogemusest kirjutamise võimaluseks oli teha seda autobiograafilistes tekstides, nagu kirjades või päevikutes, s.t tekstides, mis ei olnud mõeldud avaldamiseks.

\section{Kokkuvõte}

Traditsiooniliselt käsitletakse patograafiat kui autobiograafilist kirjutist haigusest või invaliidsusest. Thomas Couseri autopatograafia käsitlus toob esile ka vastupanu, vastudiskursuse võimaluse - autopatograafia vastustab selliseid diskursusi, mis stigmatiseerivad haiget inimest kui patoloogilist. Patograafia levinud vormiks on raamatumahus haigusnarratiiv, ent haiguse kujutusi võib leida ka teistsugustest autobiograafilistest tekstidest, nagu päevikud või kirjad.

Ilmi Kolla kirjad kajastavad ta haiguse kulgu, esitades seda autori vaatenurgast, kuid kohandades vaatepunkti vastavalt adressaadile. Nii kirjutab Ilmi Kolla emale oma haigusest optimistlikumas toonis kui luuletaja Debora Vaarandile, kellele saadetud kirjad on murelikumad. Kirjad toovad esile haiguse eri tahke ning kirjakirjutaja meeleolu seoses haigusega, andes ka ettekujutuse sanatooriumi- ja haiglaelust. Vastavalt haiguse arengule muutub haigus Ilmi Kolla kirjades järk-järgult nähtavamaks, hõlmates rohkem ruumi. Ilmi Kolla elu viimase poolaasta jooksul haiglast saadetud kirjades on haigus kujunenud üheks peateemaks.

Kuna kirjad on fragmentaarsed tekstid, mida eraldab üksteisest ajalis-ruumiline distants, kajastub see ka haigusnarratiivis, mille kirjad konstrueerivad. Kuigi sellisel haigusnarratiivil puudub koherentsus, mis on omane traditsioonilisele lineaarsele autobiograafilisele tekstile, nagu nt elulugu või päe- 
vik, saab ka kirjades esitatud haiguse lugu käsitada autopatograafia vaatenurgast.

Avaldamata tekstidena võivad kirjad nii kajastada kui ka vastustada ajastu diskursusi. Ilmi Kolla kirjades avalduv haiguse ja haige keha kujutamine funktsioneerib vastudiskursusena stalinismiajastu kehakujutusele, mis rõhutas tervet, tugevat ja jõulist naisekeha. Sellisena toob kirjade haiguskujutus esile haigusega seotud kultuurilised ja soolised tähendused, haiguse kui kultuurilise konstruktsiooni.

\section{Kommentaar}

${ }^{1}$ Artikkel on valminud sihtfinantseeritava teema "Kultuuriloo allikad ja kirjanduse kontekstuaalsus" (SF0030065s08) toetusel.

\section{Arhiiviallikad}

EKLA f 220 = Eesti Kultuurilooline Arhiiv: Ilmi Kolla fond.

\section{Kirjandus}

Couser, Thomas G. 1997. Recovering Bodies. Illness, Disability and Life Writing. Madison: The University of Wisconsin Press.

Couser, Thomas G. 1999. Autopathography: Women, Illness and Life Writing. Brownley, Martine Watson \& Kimmich, Allison B. (toim). Women and Autobiography. Wilmington: Scholarly Resources Inc., lk 163-173.

Jolly, Margaretta (toim) 2001. Encyclopedia of Life Writing. Autobiographical and Biographical Forms. I, II. London \& Chicago: Fitzroy Dearborn Publishers.

Haugen, Hayley Mitchell 2006. Writing the "Self-determined" Life: Representing the Self in Disability Narratives by Leonard Kriegel and Nancy Mairs. Ohio: College of Arts and Sciences, Ohio University (http://www.ohiolink.edu/etd/send-pdf.cgi?ohiou1147369805 - 15. juuli 2010).

Hawkins, Anne Hunsaker 1999. Reconstructing Illness. Studies in Pathography. 2. trükk. West Lafayette: Purdue UP.

Kass, Irja 2008. Kuidas ma lähen. Tallinn: Varrak.

Kleinmann, Arthur 1988. The Illness Narratives. Suffering, Healing and the Human Condition. New York: Basic Books.

Raudkivi, Aive 2003. Pilvedesse poodud lind: 16 kirja haigla-aastatest 2001-2003. Tallinn: Eesti Ekspressi kirjastus. 
Riessman, Catherine Kohler 2002. Illness Narratives: Positioned Identities. Wales: Cardiff University (http://www.cardiff.ac.uk/encap/hcrc/comet/prog/narratives.pdf - 15. juuli 2010).

Rothman, Sheila M. 1995. Living in the Shadow of Death. Tuberculosis and the Social Experience of Illness in American History. Baltimore \& London: The John Hopkins University Press.

Sontag, Susan 2002. Haigus kui metafoor. Aids ja selle metafoorid. Tallinn: Varrak. [Originaal 1978. Illness as metaphor. New York: Farrar, Straus and Giroux.]

Vääri, Eduard \& Kleis, Richard \& Silvet, Johannes 2000. Võõrsõnade leksikon. Tallinn: Valgus.

\section{Summary}

\section{Depiction of Disease in the Letters of Poet Ilmi Kolla}

\section{Eve Annuk}

Key words: correspondence, illness narrative, Ilmi Kolla, pathography, tuberculosis

Private letters are the least researched genre of autobiographical writings. Irrespective of this fact, letters can indeed offer abundant research material about the ailing person's perceptions of the disease and how he/she depicts this in writing. The article dwells upon the depiction of disease, based on the letters by Ilmi Kolla (1933-1954), using the concept of (auto)pathography as an analytical means. The focus is on how the illness is being textualised in letters and how the epistolary genre affects such a depiction.

Ilmi Kolla's letters reflect the progress of her disease, presenting this from the author's viewpoint, yet adapting it according the addressees - e.g., Ilmi Kolla's letters to her mother are written in a more optimistic tone regarding her illness than the ones to poet Debora Vaarandi expressing greater concern. The letters reveal various facets of the disease and her state of mind with regard to the illness, presenting a picture of sanatorium and hospital treatment. In line with the growing severity of Ilmi Kolla's disease, the illness becomes gradually more visible in her letters, encompassing increasing textual space. Thus, the ailment has become one of the main topics in I. Kolla's letters sent from the hospital during the last six months of her life.

The fact that letters tend to be fragmentary texts separated from each other by a temporal-spatial distance becomes evident in the narrative of disease constructed by the letters. Although such an illness narrative lacks coherence intrinsic of a traditional linear autobiographic text, such a life history or a diary, an epistolary story of an illness can be studied from the viewpoint of auto-pathography as the letters create an autobiographic description of the illness. 
As unpublished texts, letters can both reflect and oppose the discourses of the time. The depiction of the disease, and that of an ailing body, revealed in Ilmi Kolla's letters, functions as a counter-discourse to the body image of the Stalinist era, which highlighted a healthy, strong and powerful female body. As such, the reflection of the disease in the letters actually brings out the cultural and gender-wise meanings related to the disease, highlighting the illness as a cultural construct. 